\title{
Absence of the Left Circumflex Artery Detected by Coronary Computed Tomography Angiography
}

\section{Sol Sirkümfleks Arter Yokluğunun Koroner Bilgisayarlı Tomografi ile Birlikte Saptanması}

\author{
(1) Aslı Tanrıvermiş Sayit, (1) ilkay Çamlıdağ, (1) Çetin Çelenk \\ Ondokuz Mayıs University Faculty of Medicine, Department of Radiology, Samsun, Turkey
}

\begin{abstract}
Congenital absence of the left circumflex artery $(\mathrm{LCX})$ is a very rare congenital coronary anomaly. It is a benign incidental finding. Coronary computed tomography angiography (CTA) is the first choice imaging modality for non-invasive visualization of coronary artery anomalies. Also, it is fast and safe. Here, we present a case with an absent LCX detected by coronary CTA in a 20-year-old man with chest pain.
\end{abstract}

Keywords: Coronary computed tomography angiography, coronary arteries, anomalies, left circumflex artery öz

Sol sirkümfleks arterin konjenital yokluğu çok nadir görülen konjenital koroner bir anomalidir. İyi huylu tesadüfi bir bulgudur. Koroner bilgisayarlı tomografi anjiyografi, koroner arter anomalilerinin invazif olmayan görüntüleme yöntemleri arasında ilk tercih edilecek görüntüleme yöntemidir. Ayrıca, hızlı ve güvenilirdir. Biz burada, göğüs ağrısı olan 20 yaşında bir erkek hastada koroner bilgisayarlı tomografi anjiyografide saptanan sol sirkümfleks arter yokluğunu sunmayı amaçladık.

Anahtar Kelimeler: Koroner bilgisayarlı tomografi anjiyografi, koroner arterler, anomaliler, sol sirkümfleks arter

\section{Introduction}

Congenital anomalies of coronary arteries are uncommon, with an incidence between $0.64 \%$ and $1.3 \%$ (1). Although these anomalies are usually benign and patients are asymptomatic, it may sometimes cause life-threatening complications such as myocardial infarction, arrhythmia, or sudden death in $20 \%$ of patients (2). Coronary artery anomalies can be classified as anomalies and variations without a shunt, anomalies with a shunt, or congenital aneurysms. Anomalies and variations without a shunt include variations in coronary artery number, the origin of vessel ostium, myocardial bridging, segmental hypoplasia, stenosis, or atresia. Anomalies with a shunt include coronary artery fistulas and coronary arteries originating from the pulmonary artery (2). The congenital absence of the left circumflex artery $(\mathrm{LCX})$ is very rare and results from the failure of LCX development in the left atrioventricular groove (3). Conventional coronary angiography (CCA) can be used for the diagnosis of coronary artery anomalies, but it is an invasive imaging method with a high radiation dose. Recently, coronary computed tomography angiography (CTA) has emerged as a non-invasive alternative for evaluation of coronary anatomy, particularly after the introduction of modern protocols allowing to perform coronary CTA with a low radiation dose (1). Moreover, it is a faster, safer, and non-invasive imaging modality with a higher accuracy rate. Here, we present a case with an absent LCX detected by coronary CTA in a 20-year-old man with chest pain.

\section{Case Report}

A 20-year-old male patient came to the emergency department with a complaint of chest pain. Physical examination and prior medical history were unremarkable. Cardiovascular examination was normal, with no additional sounds or murmur. Complete blood count, biochemistry, and cardiac enzymes [creatine kinase (CK), CK-MB, and troponin T] were within normal limits. Electrocardiogram revealed normal sinus rhythm, the normal axis with no ischemic changes. Also, echocardiography was normal, with no structural abnormalities, normal ejection fraction, and no regional dyskinesia. Upon continuation of the patient's angina, 64-section multislice coronary CTA was performed to exclude coronary artery disease or anomalies. Coronary CTA showed that the right coronary artery (RCA) originated from the right sinus of Valsalva, and the left main coronary artery (LMCA) originated from the left sinus Valsalva. Coronary CTA revealed a long LMCA (Figure 1), normal left anterior descending 
(LAD), and absence of LCx with superdominant RCA and no obstructive lesion of the coronary arteries (Figure 2). Lateral and posterior aspects of the left ventricle were supplied by a superdominant RCA and a large first diagonal artery (Figure 3). The patient was diagnosed with the absence of LCx. No treatment was planned because the patient had no arrhythmia. The patient was informed about his diagnosis, and he was discharged.

Informed consent was obtained from the patient.

\section{Discussion}

The congenital absence of LCX is very rare, and its incidence varies between $0.003-0.067 \%$ (3). Upon the absence of the LCX, the lateral wall of the left ventricle is supplied by a superdominant RCA or occasionally by multiple diagonal branches of LAD. Congenital absence of LCX is an incidental benign finding. However, it may cause significant symptoms in $20 \%$ of patients (4). Congenital coronary artery anomalies should be

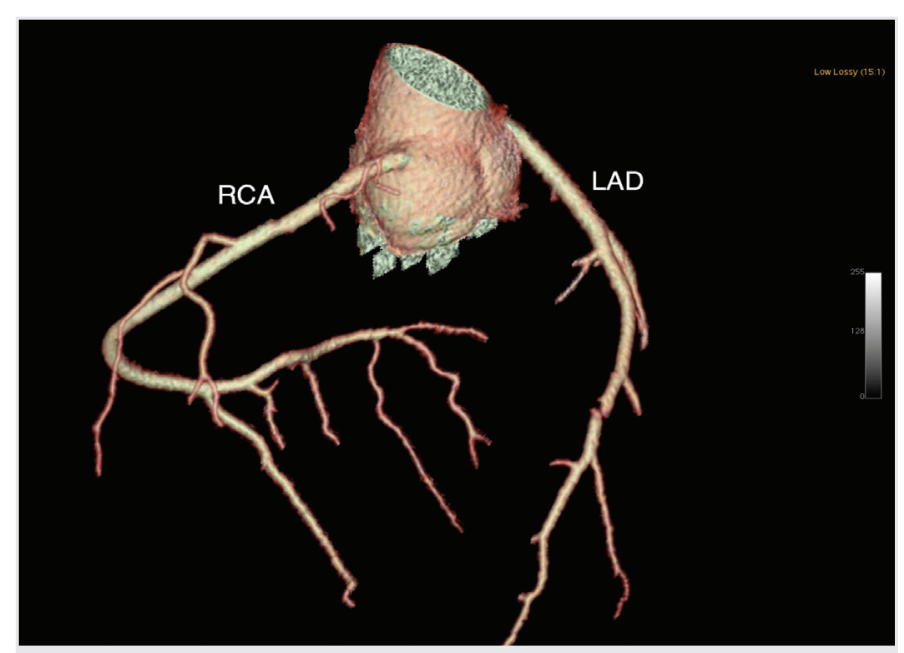

Figure 1. Three-dimensional volume-rendered (3D-VR) image shows the normal course of the right coronary artery and left anterior descending RCA: right coronary artery, LAD: left anterior descending

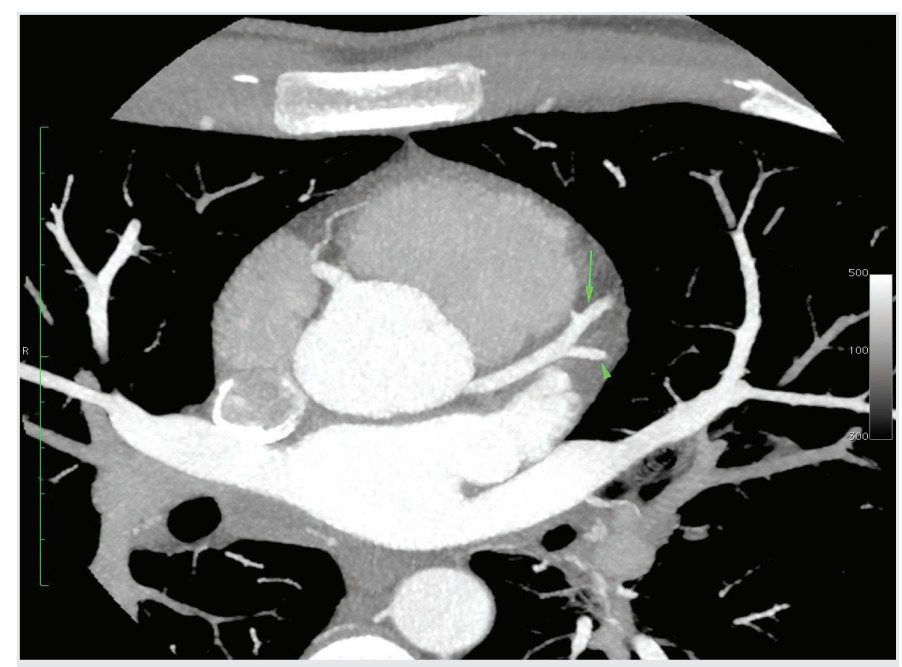

Figure 2. Coronary computed tomography angiography shows a long left main coronary artery, normal left anterior descending (arrow), first diagonal artery (arrowhead), and absence of left circumflex artery with superdominant right coronary artery distinguished from pericarditis, myocarditis, myocardial infarction, and musculoskeletal tenderness, especially in patients with chest pain (5).

Transthoracic echocardiography (TTE), transesophageal echocardiography (TEE), cardiac magnetic resonance imaging, coronary CTA and CCA can be used to diagnose coronary artery anomalies and to rule out other cardiac pathologies (4). TTE and TEE have limitations in diagnosing the coronary artery anomalies, including an inability to visualize the coronary arteries. CCA and coronary CTA are the preferred methods for the evaluation of coronary arteries (4). Asymptomatic patients with coronary artery disease who are low to an intermediate-risk group for the coronary artery disease, coronary BTA is the first choice imaging modality in order to exclude coronary artery anomalies due to being non-invasive, rapid, reliable and having a low radiation dose. Ghadri et al. (6) reported that the prevalence of coronary artery anomalies detected by coronary CTA was significantly higher than that of CCA (7.85\% versus $2.02 \% ; p<0.01)$. Also, coronary artery origin, course, termination of the coronary arteries, and their relationship to cardiac and non-cardiac structures can be better evaluated with coronary CTA than the CCA (4). Therefore, coronary CTA should be the first-line imaging method for the assessment of known or suspected coronary anomalies in patients with low risk for coronary artery disease. However, CCA should be performed in patients who are suspected of having coronary artery disease and will be undergoing interventional procedures during imaging (4). There is no specific treatment for the absence of $\mathrm{LCX}$, but it should be differentiated from the total occlusion of Lcx because their treatment approach differs (4). If RCA is totally occluded in a patient with absent LCX, myocardial infarction may develop in the inferior, posterior, and lateral walls (5). Therefore, early diagnosis and treatment may be lifesaver in these patients.

In our case, the absence of LCx presented with superdominant RCA, and no stenosis or occlusion was detected in the coronary arteries. No specific treatment was given to the patient. The patient was discharged with information about his condition.

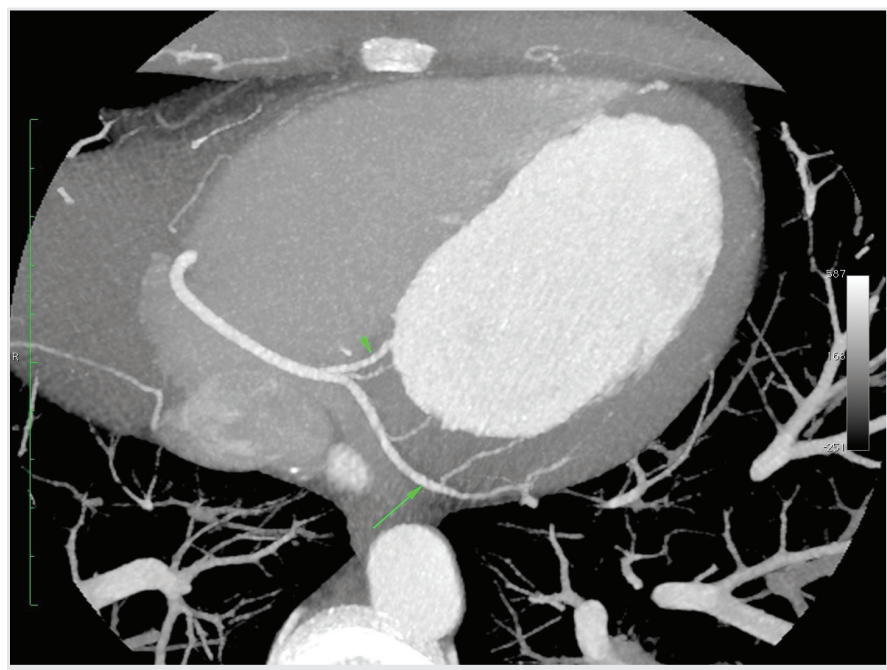

Figure 3. Coronary computed tomography angiography shows welldeveloped posterolateral branches (arrow) and posterior descending artery (arrowhead) of the right coronary artery 


\section{Conclusion}

Congenital absence of LCX is an extremely rare anomaly of coronary arteries resulting from the failure of $L C x$ development in the left atrioventricular groove. Coronary CTA should be the first-line imaging method for the assessment of known or suspected coronary anomalies in patients with a low risk for coronary artery disease. There is no specific treatment for the absence of LCX, but it should be differentiated from the total occlusion of LCX.

Informed Consent: Informed consent was obtained from the patient.

Peer-review: Externally peer-reviewed.

Author Contributions: Surgical and Medical Practices - A.T.S., Ç.C.., I.C..; Concept - A.T.S., C..C., I.C..; Design - A.T.S., I.C..; Data Collection and/or Processing - A.T.S., C.C..; Analysis and/or Interpretation - A.T.S., C.C.., I.C..; Literature Search - A.T.S.; Writing Manuscript - A.T.S., I.Ç.

Conflict of Interest: There is no conflict of interest with any institution or company.

Financial Support: The authors declared that they did not receive financial support for this study.

\section{References}

1. Hongsakul K, Suwannanon R. Congenital absence of left circumflex artery detected by computed tomography coronary angiography: a case report. Case Rep Vasc Med 2012; 2012: 204657.

2. Tanrivermis Sayit A, Celenk C. Hypoplastic left circumflex coronary artery: Imaging findings with coronary computed tomography angiography. Current Medical Imaging Reviews 2018; 14: 1.

3. Villa ADM, Sammut E, Nair A, Rajani R, Bonamini R, Chiribiri A. Coronary artery anomalies overview: The normal and the abnormal. World J Radiol 2016; 8: 537-55.

4. Ullah S, Khan M, Khan NAJ, Zeb H, Patel R. Absence of left circumflex artery: A rare congenital disorder of coronary arteries. Case Rep Cardiol 2017; 2017 8710135.

5. Guterbaum TJ, Øvrehus KA, Veien KT, Møller JE, Mickley H. Left circumflex artery agenesis in young male. Am J Case Rep 2018; 19: 517-22.

6. Ghadri JR, Kazakauskaite E, Braunschweig S, Burger IA, Frank M, Fiechter $\mathrm{M}$, et al. Congenital coronary anomalies detected by coronary computed tomography compared to invasive coronary angiography. BMC Cardiovasc Disord 2014; 14: 81 . 